\title{
Sistem Pendukung Keputusan Seleksi Calon Karyawan Baru PT. Dawam Prima Perkasa Menggunakan Metode Aras Berbasis Web
}

\section{Decision Support System for New Employees Candidat Selection PT. Dawam Prima Perkasa Using Aras Method Web Based}

\author{
Saifur Rohman Cholil ${ }^{1}$, Enggar Satrio Prisiswo ${ }^{1}$ \\ ${ }^{1}$ Program Studi Sistem Informasi, Fakultas Teknologi Informasi dan Komunikasi, Universitas Semarang
}

ARTICLE INFO

Article history:

Diterima 19-09-2020

Diperbaiki 15-12-2020

Disetujui 29-12-2020

Kata Kunci:

Sistem Pendukung

Keputusan, Seleksi Calon

Karyawan Baru, Aras
ABSTRAK

Karyawan merupakan salah satu faktor pendukung bagi sebuah perusahaan, karena dengan memiliki karyawan yang berkualitas, sesuai dengan kualifikasi dan kriteria yang dibutuhkan perusahaan barulah perusahaan tersebut dapat berkembang dan bergerak maju di masa depan. Tidak terkecuali PT. Dawam Prima Perkasa yang sedang membutuhkan karyawan baru yang sesuai untuk bekerja diperusahaan. Namun PT. Dawam Prima Perkasa dihadapkan dengan sebuah masalah dimana dengan banyaknya calon karyawan yang mengikuti tes seleksi, maka akan menimbulkan banyaknya berkas yang masuk harus disesuaikan dengan kriteria yang dimiliki perusahaan serta membutuhkan waktu yang tidak sedikit, sehingga rentan terjadinya kekeliruan berkas. Untuk meminimalisir terjadinya kesalahan serta lama waktu yang digunakan, dibuatlah suatu Sistem Pendukung Keputusan untuk menentukan calon karyawan terbaik yang akan bekerja diperusahaan. Metode Sistem Pendukung Keputusan yang digunakan adalah Additive Ratio Assessment (ARAS). Penelitian ini telah melalui proses validasi korelasi rank spearman dan diperoleh nilai sebesar 0,950. Berdasarkan hasil tersebut, metode $A R A S$ dapat digunakan dalam menyeleksi calon karyawan baru pada PT. Dawam prima Perkasa.

\section{A B S T R ACT}

Employees are one of the supporting factors for a company, because by having qualified employees, according to the qualifications and criteria needed by the company, then the company can develop and move forward in the future. No exception, PT. Dawam Prima Perkasa who is in need of new employees who are suitable to work in the company. However, PT. Dawam Prima Perkasa is faced with a problem where the large number of prospective employees who take the selection test will cause the number of incoming files to be adjusted to the criteria owned by the company and require a lot of time, making it prone to file errors. To minimize the occurrence of errors and the length of time used, a Decision Support System was created to determine the best prospective employees who will work in the company. The Decision Support System Method used is the Additive Ratio Assessment (ARAS). This research has gone through the process of validating the Spearman rank correlation and the value is 0.950. Based on these results, the ARAS method can be used in selecting prospective new employees at PT. Dawam prima Perkasa.

\section{Pendahuluan}

Karyawan merupakan salah satu faktor pendukung bagi sebuah perusahaan, karena dengan memiliki karyawan yang berkualitas sesuai dengan kualifikasi dan kriteria yang dibutuhkan perusahaan, barulah perusahaan tersebut akan berkembang dan bergerak maju di masa depan. Proses seleksi karyawan merupakan langkah yang dilakukan perusahaan untuk mendapatkan calon karyawan baru dengan standar kualifikasi dan kriteria yang dibutuhkan oleh perusahaan. Tahapan selanjutnya adalah seleksi manajemen, berperan untuk menentukan dan memilih calon karyawan baru dan menempatkannya susuai dengan posisi yang tepat didalam perusahaan, dengan demikian, kemampuan dan kualitas 
karyawan tersebut akan dapat lebih cepat berkembang dikarenakan karyawan tersebut bekerja sesuai dengan kompetensi keahlian yang mereka miliki [1].

PT. Dawam Prima Perkasa adalah sebuah perusahaan tepatnya terletak di Jl. Tlogo Timur II No. 3-4 Kec. Pedurungan, Kab. Semarang, yang merupakan salah satu perusahaan yang bergerak di bidang kontraktor, supplier dan general trading. Disetiap tahunnya PT. Dawam Prima Perkasa membutuhkan calon karyawan baru untuk membantu dalam setiap pekerjaan untuk masing-masing divisi didalam perusahaan dikarenakan banyaknya pekerjaan yang harus dilakukan dikarenakan bekerja sama dengan banyak pihak seperti salah satunya yaitu PT. PERTAMINA (Persero). Seringali pihak dari perusahaan yang menangani penerimaan calon karyawan baru dihadapkan dengan beberapa permasalahan yaitu proses seleksi yang lama, masih menggunakan $M S$. Excel untuk perhitungan penilaian calon karyawan, kesalahan dan kekeliruan berkas menjadi hal yang rentan untuk dihadapi, dikarenakan begitu banyak berkas yang masuk harus disesuaikan dengan begitu banyak kriteria yang dimiliki oleh perusahaan. Sehingga untuk menghadapi masalah yang terjadi dibuatlah suatu sistem yang dapat memecahkan suatu permasalahan didalam perusahaan, yaitu Sistem pendukung Keputusan (SPK) dimana dapat membantu pihak manajemen dalam mengambil keputusan yang berkaitan dengan masalah yang semi terstruktur. Sistem ini memiliki kelebihan dimana dapat menentukan alternatif terbaik yang ada sehingga dapat membantu dalam pengambilan keputusan secara akurat [2].

Metode yang digunakan penulis dalam Sistem Pendukung Keputusan adalah menggunakan metode Addititive Ratio Assessment (ARAS), karena lebih mudah dalam menentukan alternatife terbaik serta menghasilkan solusi atau keputusan yang lebih optimal dalam setiap perhitungan. Karena didalam Metode Perhitungan Aras yang tidak ada dalam metode lainya adalah konsep perangkingan yang berdasarkan pada konsep perangkingan Utility Degree, yaitu dengan membandingkan nilai keseluruhan alternatif optimal terhadap nilai keseluruhan setiap alternatif, sehingga dapat sangat membantu dalam menentukan penilaian terhadap para calon karyawan dan menentukan calon karyawan terbaik sesuai dengan standar kualifikasi bagi perusahaan [3].

Proses seleksi calon karyawan tersebut diukur dari beberapa kriteria penilaian. Kriteria penilaian tersebut adalah Tes Psikotest, Wawancara, Tes Kesehatan, Pendidikan, Pengalaman kerja, Usia, Status dan Alamat. Berdasarkan pada kriteria yang sudah ditentukan oleh perusahaan Sistem Pendukung Keputusan berhasil dibuat, yang dapat digunakan untuk memudahkan perusahaan dalam menyeleksi calon karyawan baru yang terbaik.

\section{Metode Penelitian}

\subsection{Penelitian Terdahulu}

Terkait penelitian terdahulu terdapat studi kasus sistem pendukung keputusan menggunakan metode aras dan beberapa penelitian terkait seleksi calon karyawan dengan menggunkan metode yang berbeda.

Berikut penelitian terdahulu yang telah dilakukan ditunjukan seperti dibawah ini.
1. Sistem Pendukung Keputusan untuk Seleksi Karyawan baru Dengan Metode Simple Additive Weighting (SAW) Berbasis Web [4]. N. Enggar pada penelitianya dalam menyeleksi calon karyawan baru di RS. PKU Muhammadiyah Kota Yogyakarta dengan menghasilkan nilai tertinggi 0,758 (Enggar Novianto). 2. Seleksi Penerimaan Karyawan Menggunakan Metode Topsis [5]. Hertyana pada penelitiannya dalam menyeleksi calon karyawan baru pada perusahaan properti menghasilkan nilai tertinggi 0,7781(C10).

3. Sistem Pendukung Keputusan Seleksi Penerimaan Karyawan Dengan Metode Analytical Hierarchy Process [6]. D. Gustian, M. Nurhasanah dan M. Arip Pada penelitiannya dalam menyeleksi calon karyawan baru pada PT. Yongjin Java Suka Garment Victory II menghasilkan nilai tertinggi 0,21231(Resna) dan telah diuji oleh 5 responden pada setiap divisi yang berbeda.

4. Analisis Penerapan Metode Additive Ratio Assessment (ARAS) pada Pemberian Insentif Sales Penjualan Guna Mendukung Keputusan [7]. S. Syafrida, S. Hafni pada penelitiannya dalam menyeleksi pemberian insentif sales mempunyai nilai tertinggi yaitu 0,0773 (A12).

5. Implementasi ARAS (Additive Ratio Assessment) Dalam Pemilihan Kasir Terbaik Studi Kasus Outlet Cardinal Store Plaza Medan Fair [3]. R. Fachrizal pada penelitiannya mempunyai nilai tertinggi yaitu 0,9960 (Rachmad Fachrizal).

6. Implementasi Metode Aras dalam pemberian keputusan bonus tahunan karyawan [8]. S. A, Joly Afriany pada penelitiannya pemberian bonus tahunan dari 15 karyawan diperoleh 5 karyawan yang memperoleh bonus tahunan dari yang terbesar sampai yang terakhir yaitu pertama dengan nilai 0,0750 (Apsah), yang kedua 0,0737 (Aisyah), yang ketiga 0,0734 (Eka), yang keempat 0,0658(Saidah) dan yang kelima adalah 0,0644 (Lija).

Berdasarkan penelitian terdahulu, yang telah di uraikan dari penelitian diatas, terdapat hasil bahwa jurnal No 1, 2 dan 3 yaitu penerapan SPK tentang seleksi calon karyawan baru menggunakan metode yang berbeda, yang dapat membantu dalam melakukan penelitian. Sedangkan Jurnal No. 4, 5 dan 6 merupakan penerapan SPK menggunakan Metode Aras dengan topik pembahasan yang berbeda, sehingga dapat membantu dalam memberikan referensi dan ajuan dalam melakukan penelitian.

Dari penelitian terdahulu, penulis dapat membangun sebuah Sistem Pendukung Keputusan dengan ajuan penelitian terdahulu menggunakan metode Aras dalam menentukan calon karyawan baru yang dibutuhkan oleh Perusahaan, hasil yang diperoleh setelah dibuatnya sistem pendukung keputusan tersebut adalah sistem dapat memberikan alternatif serta solusi dan manfaat dalam pengambilan keputusan terhadap calon karyawan yang akan diterima diperusahaan secara lebih cepat, tepat dan akurat, pada penerimaan calon karyawan yang telah terjadi sebelumnya di PT. Dawam prima Perkasa setelah menggunakan sistem dapat secara rinci memberikan informasi penilaian terhadap calon karyawan yang diterima sesuai dengan ranking dan nilai yang telah terdaftar, sehingga perusahaan dapat memilih calon kandidat yang tepat secara akurat selain. Sehingga dengan mempunyai karyawan yang berkemampuan dan berkualitas dengan hasil kerja yang berkualitas pula dapat membantu perusahaan untuk bergerak maju dan mencapai tujuan. 


\subsection{Sistem Pendukung Keputusan (SPK)}

Sistem Pendukung Keputusan adalah faktor penting didalam pengambilan sebuah keputusan yang tidak terstruktur maupun terstruktur dikarenakan Sistem Pendukung keputusan memang dirancang untuk membantu mempercepat dan memudahkan perusahaan atau intansi dalam mendukung seluruh tahap pengambilan sebuah keputusan.

Michael Scoot Morton pada tahun 1971 adalah seseorang yang pertama kali mengungkapkan Sistem Pendukung Keputusan dengan istilah yang dikenal dengan Management Decision System, Setelah itu sejumlah lembaga perguruan tinggi, lembaga penelitian dan perusahaan mulai melakukan penelitian untuk membangun Sistem Pendukung Keputusan, sehingga dapat disimpulkan bahwa Sistem Pendukung Keputusan merupakan suatu sistem berbasis komputer yang memang ditujukan untuk membantu pengambilan keputusan dengan memanfaatkan data dan model tertentu untuk memecahkan berbagai masalah yang tidak terstruktur [2].

Sebagai salah satu faktor pendukung manajemen dalam menangani permasalahan yang tidak terstruktur maupun yang terstruktur dengan menggunakan data dan model melalui salah satu informasi berbasis komputer yang menghasilkan berbagai alternatif dalam penentuan sebuah keputusan yaitu Sistem Pendukung Keputusan [9].

\subsection{Additive Ratio Assessment (ARAS)}

Salah satu metode didalam Sistem Pendukung Keputusan yang menggunakan nilai fungsi utilitas untuk menentukan hasil dari mengikutsertakan alternatif optimal ke dalam proses perhitungan sebelum digunakan sebagai data baseline dalam menentukan alternatif terbaik. Dimana rasio dari jumlah nilai kriteria akan diukur dan dinormalisasikan berdasarkan alternatif optimal. Alternatif optimal adalah alternatif terbaik yang nantinya akan dibandingkan dengan nilai keseluruhan setiap alternatif, adalah alur perhitungan dari Metode Perhitungan Aras [10].

Perhitungan Metode Additive Ratio Assessment (ARAS) dapat diartikan sebagai satu-satunya metode sistem pendukung keputusan yang dalam perangkinganya menggunakan konsep perangkingan Utility Degree, yaitu dengan membandingkan nilai indeks keseluruhan alternatif optimal terhadap nilai indeks keseluruhan setiap alternatif [3].

Berikut langkah perhitungan menerapkan metode ARAS, yaitu: 1. Menentukan kriteria, bobot, alternatif dan menentukan nilai alternatif dari setiap kriteria serta menentukan nilai optimal benefit dan cost.

2. Merubah nilai kriteria menjadi matriks keputusan.

$x=\left[\begin{array}{cccc}X 01 & X 0 j & \ldots & X 0 n \\ X i 1 & X i j & \ldots & X i n \\ \vdots & \vdots & \ddots & \vdots \\ X n 1 & X m j & \ldots & X m n\end{array}\right](i=0, m \ldots j=1, n)$

Dimana :

$m \quad$ = jumlah alternatif

$n \quad=$ jumlah kriteria

$X i j=$ nilai performa dari alternatif $i$ terhadap kriteria $j$

$X 0 j \quad=$ nilai optimal dari kriteria $j$

3. Menentukan nilai optimal kriteria j $(X 0 j)$ yaitu dengan cara:
$X 0 j=\frac{\max }{i} . X i j$, if $\frac{\max }{i} . X i j$ is preferable

$X 0 j=$

$\frac{\min }{i}$. Xij, if $\frac{\min }{i}$.Xij is prefable

4. Menentukan normalisasi matriks keputusan dari semua kriteria mempunyai dua cara yaitu:

Perhitungan dengan kategori Benefit

Dimana $X i j$ adalah nilai normalisasi

$x_{i j}=$

$\frac{x_{i j}}{\sum_{i=0}^{m} x_{i j}}$

Perhitungan dengan kategori Cost mempunyai dua cara yaitu :

1. $x_{i j} \frac{1}{x_{i j}}$

2. $R=\frac{x_{i j}}{\sum_{i=0}^{m} x_{i j}}$.

5. Menentukan pembobotan pada matriks yang sudah dinormalisasi :

$D=[d i j] m x n=r i j$

Dimana

$W_{j}=$ bobot kriteria $j$

6. Menentukan nilai fungsi optimalisasi $(\mathrm{Si})$ :

$s_{i}=\sum_{j=1}^{n} d i j ;(i=1,2 \ldots, m ; j=1,2 \ldots, n)$.

Dimana $S i$ merupakan fungsi optimalisasi alternatif $i$. Nilai terbesar adalah nilai yang terbaik dan nilai terkecil merupakan nilai yang terburuk. Nilai dan bobot kriteria yang berhubungan akan berpengaruh pada hasil akhir.

7. Langkah terakhir adalah menentukan nilai Derajat Utilitas (Peringkat) dengan menggunakan rumus:

$k_{i}=\frac{s_{i}}{s_{0}}$

Dimana Hasil dari $S i$ dan $S O$ merupakan nilai kriteria optimalitas (perangkingan)

\subsection{Metode Prototype}

Metode prototipe adalah salah satu metode pengembangan perangkat lunak yang banyak digunakan. Dengan menggunakan metode prototipe pengembang (development) dan pelanggan (Customer) dapat saling berinteraksi selama proses pembuatan sistem. Seringkali terjadi seorang customer hanya mendefinisikan secara umum apa saja yang dibutuhkan, pemrosesan dan data-data apa saja yang dibutuhkan, menjadikan kurangnya paham seorang pengembang dalam pembuatan algoritma dan pembuatan sistem yang akan dibuatnya.

Model prototipe dapat digunakan untuk menyambungkan ketidakpahaman customer mengenai hal teknis dan memperjelas spesifikasi kebutuhan yang diinginkan customer kepada pengembang perangkat lunak Model Prototipe (Prototyping Model) dimulai dari mengumpulkan kebutuhan customer terhadap perangkat lunak yang akan dibuat. Program prototipe biasanya merupakan program yang belum jadi. Program ini menyediakan tampilan dengan simulasi alur perangkat lunak sehingga tampak seperti perangkat lunak yang sudah jadi.

Berikut ini adalah Metode Prototipe seperti pada Gambar 1: 


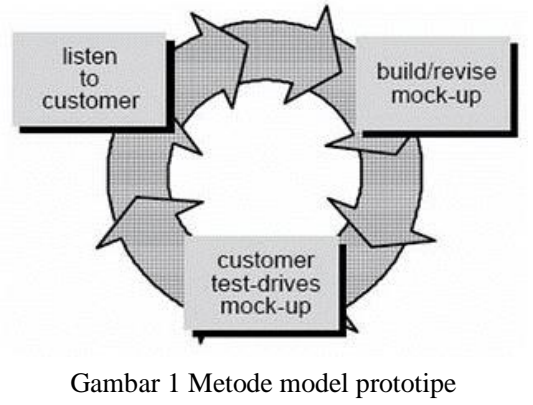

Penjelasan Metode Prototype:

1. Lisen To Customer (Mendengarkan pelanggan)

Pada tahap ini dilakukan pengumpulan kebutuhan dari sistem dengan cara mendengar keluhan dari customer. Untuk membuat suatu sistem yang sesuai kebutuhan, maka harus diketahui terlebih dahulu bagaimana sistem yang sedang berjalan untuk kemudian mengetahui masalah yang terjadi. Pada tahap ini metode pengumpulan data yang telah didapat dapat dijadikan acuan dalam pembuatan sistem yang akan diimplementasikan sesuai dengan masalah yang ada di PT. Dawam Prima Perkasa.

2. Build / Revise Mock-up (Merancang dan Membuat Prototipe)

Pada tahap ini, dilakukan perancangan dan pembuatan prototipe sistem, dibuat dengan disesuaikan kebutuhan sistem yang telah didefinisikan sebelumnya dari keluhan customer atau pengguna. Pada tahap ini akan dilakukan perancangan sistem yang akan digunakan adalah UML (Unified Modelling Language), dengan Bahasa Pemrograman PHP (Hyper Text Preprocessor) dan Database MySQL serta Sisem Pendukung Keputusan Metode Additive Ratio Assessment (ARAS), sebagai dasar perhitungan dalam sistem.

3. Customer Test Drives Mock-up (Uji Coba)

Pada tahap ini, prototype dari sistem di uji coba oleh customer atau pengguna. Kemudian dilakukan evalusasi kekurangan-kekurangan dari kebutuhan customer. Pengembangan kemudian kembali mendengarkan keluhan dari customer untuk memperbaiki Prototype yang ada. Pada tahap ini setelah prototype sistem pendukung keputusan seleksi calon karyawan baru menggunakan metode aras berbasis web diuji coba oleh perusahaan maka keluhan atau masalah yang ada di sistem ini akan segera diatasi guna memperbaiki sistem secara sempurna dan agar dapat digunakan dan memudahkan perusahaan dalam perekrutan karyawan baru.

\section{Analisis dan Pembahasan}

\subsection{Analisis}

Pada PT. Dawam prima Perkasa yang setiap tahunnya selalu membutuhkan karyawan baru untuk membantu disetiap divisi baru yang dibutuhkan perusahaan. Proses seleksi calon karyawan dibutuhkan suatu sistem yang dapat membantu dalam membuat keputusan secara cepat dan tepat serta akurat. Untuk mempercepat dalam penyeleksian calon karyawan baru dan memudahkan serta membantu perusahaan dalam menentukan calon karyawan yang sesuai dengan kualifikasi dan kriteria yang diinginkan perusahaan maka dibutuhkanya sistem pendukung keputusan. Metode yang akan digunakan pada sistem pendukung keputusan adalah metode Aras.
Proses seleksi calon karyawan tersebut diukur dari beberapa kriteria penilaian. Penentuan dari kriteria penilaian didapatkan pada saat interview dengan pihak perusahaan PT. Dawam Prima Perkasa, kriteria penilaian tersebut adalah Tes Psikotest, Wawancara, Tes Kesehatan, Pendidikan, Pengalaman kerja, Usia, Status dan Alamat sedangkan penentuan dari bobot kriteria yang sudah ditentukan oleh PT. Dawam Prima Perkasa, yaitu dari yang terpenting 20\%, cukup penting $15 \%, 10 \%$ dan kurang penting $5 \%$, dimana menghasilkan nilai dengan perbandingan $100 \%$ dari masing-masing kriteria, nilai yang terpenting atau yang diprioritaskan mempunyai bobot yang tertinggi dibandingkan dengan yang lain dikarenakan menjadi prioritas utama perusahaan. Sedangkan penentuan dari benefit dan cost juga didapat dari penentuan kriteria prioritas utama yang sudah ditentukan perusahaan dengan acuan dari kriteria penilaian dan bobot kriteria.Berikut merupakan kriteria seperti ditunjukkan pada Tabel 1.

Tabel 1.

Tabel Kriteria

\begin{tabular}{cccc}
\hline Kriteria & Keterangan & Bobot & Jenis \\
\hline C1 & Test Psikotest & 20 & Benefit \\
C2 & Wawancara & 20 & Benefit \\
C3 & Tes Kesehatan & 10 & Benefit \\
C4 & Pendidikan & 15 & Benefit \\
C5 & Pengalaman Kerja & 20 & Benefit \\
C6 & Usia & 5 & Benefit \\
C7 & Status & 5 & Cost \\
C8 & Alamat & 5 & Cost \\
\hline
\end{tabular}

Berikut adalah data-data yang dijadikan sebagai data alternatif, dalam hal ini merupakan contoh calon karyawan baru seperti ditunjukkan pada Tabel 2.

Tabel 2.

Tabel Alternatif

\begin{tabular}{clccc}
\hline Alternatif & \multicolumn{1}{c}{ Nama } & C1 & C2 & C3 \\
\hline A0 & Nilai Optimal & 4 & 4 & 5 \\
A1 & Sigid Ahmad Diyono & 4 & 2 & 5 \\
A2 & Irfan Zamrudi & 3 & 3 & 3 \\
A3 & Ardian Wiraksa & 4 & 4 & 1 \\
A4 & Eryanda Susilo & 3 & 4 & 3 \\
A5 & Joni Iskandar & 4 & 2 & 5 \\
\hline
\end{tabular}

Tabel 3.

Lanjutan Tabel Alternatif

\begin{tabular}{ccccc}
\hline C4 & C5 & C6 & C7 & C8 \\
\hline 5 & 5 & 5 & 3 & 3 \\
3 & 5 & 3 & 3 & 5 \\
4 & 4 & 4 & 3 & 3 \\
4 & 1 & 4 & 5 & 4 \\
3 & 5 & 3 & 3 & 5 \\
5 & 1 & 5 & 5 & 3
\end{tabular}


Pada Tabel 1, 2 dan 3 dapat menjelaskan bahwa Data Awal diantaranya adalah Alternatif, Kriteria dan Bobot. Alternatif didapatkan dari data nama calon karyawan. Sedangkan Kriteria didapatkan dari data nilai yang sudah dilakukan oleh calon karyawan pada saat tes seleksi di perusahaan. Data Bobot didapatkan dari data kriteria yang sudah ditentukan nilai bobotnya oleh Perusahaan. Nilai Optimal didapatkan dari Benefit dan Cost, dimana jika Benefit akan diambil nilai yang tertinggi dan jika Cost akan diambil nilai yang terendah dari masing-masing nilai alternatif.

Selanjutnya dalam Perhitungan Metode Aras adalah sebagai berikut.

2. Menentukan Matrix Keputusan

$X=\left[\begin{array}{llllllll}4 & 4 & 5 & 5 & 5 & 5 & 3 & 3 \\ 4 & 2 & 5 & 3 & 5 & 3 & 3 & 5 \\ 3 & 3 & 3 & 4 & 4 & 4 & 3 & 3 \\ 4 & 4 & 1 & 4 & 1 & 4 & 5 & 4 \\ 3 & 4 & 3 & 3 & 5 & 3 & 3 & 5 \\ 4 & 2 & 5 & 5 & 1 & 5 & 5 & 3\end{array}\right]$

3. Menormalisasikan Matrix Keputusan untuk semua Kriteria $R_{i j}=\frac{\text { Nilai kriteria }}{\text { Jumlah Nilai semua kriteria }}=$ Hasil (Benefit) (C1)

$R_{01}=\frac{4}{4+4+3+4+3+4}=0,182$

$R_{11}=\frac{4}{4+4+3+4+3+4}=0,182$

$R_{21}=\frac{3}{4+4+3+4+3+4}=0,136$

$R_{31}=\frac{4}{4+4+3+4+3+4}=0,182$

$R_{41}=\frac{3}{4+4+3+4+3+4}=0,136$

$R_{51}=\frac{4}{4+4+3+4+3+4}=0,182$

(C2)

$R_{02}=\frac{4}{4+2+3+4+4+2}=0,211$

$R_{12}=\frac{2}{4+2+3+4+4+2}=0,105$

$R_{22}=\frac{3}{4+2+3+4+4+2}=0,158$

$R_{32}=\frac{4}{4+2+3+4+4+2}=0,211$

$R_{42}=\frac{4}{4+2+3+4+4+2}=0,211$

$R_{52}=\frac{2}{4+2+3+4+4+2}=0,105$

(C3)

$R_{03}=\frac{5}{5+5+3+1+3+5}=0,227$

$R_{13}=\frac{5}{5+5+3+1+3+5}=0,211$

$R_{23}=\frac{3}{5+5+3+1+3+5}=0,136$

$R_{33}=\frac{1}{5+5+3+1+3+5}=0,045$
$R_{43}=\frac{3}{5+5+3+1+3+5}=0,136$
$R_{53}=\frac{5}{5+5+3+1+3+5}=0,227$

(C4)

$R_{04}=\frac{5}{5+3+4+4+3+5}=0,208$

$R_{14}=\frac{3}{5+3+4+4+3+5}=0,125$

$R_{24}=\frac{4}{5+3+4+4+3+5}=0,167$

$R_{34}=\frac{4}{5+3+4+4+3+5}=0,167$

$R_{44}=\frac{3}{5+3+4+4+3+5}=0,125$

$R_{54}=\frac{5}{5+3+4+4+3+5}=0,208$

(C5)

$R_{05}=\frac{5}{5+5+4+1+5+1}=0,238$

$R_{15}=\frac{5}{5+5+4+1+5+1}=0,238$

$R_{25}=\frac{4}{5+5+4+1+5+1}=0,190$

$R_{35}=\frac{1}{5+5+4+1+5+1}=0,048$

$R_{45}=\frac{5}{5+5+4+1+5+1}=0,238$

$R_{55}=\frac{1}{5+5+4+1+5+1}=0,048$

(C6)

$R_{06}=\frac{5}{5+3+4+4+3+5}=0,208$

$R_{16}=\frac{3}{5+3+4+4+3+5}=0,125$

$R_{26}=\frac{4}{5+3+4+4+3+5}=0,167$

$R_{36}=\frac{4}{5+3+4+4+3+5}=0,167$

$R_{46}=\frac{3}{5+3+4+4+3+5}=0,125$

$R_{56}=\frac{5}{5+3+4+4+3+5}=0,208$

(C7)

Tahap 1:

$X_{i j}=\frac{1}{\text { Nilai Kriteria }}=X_{i j} *($ Cost $)$

$X_{07}=\frac{1}{3}=0,333$

$X_{17}=\frac{1}{3}=0,333$

$X_{27}=\frac{1}{3}=0,333$

$X_{37}=\frac{1}{5}=0,200$

$X_{47}=\frac{1}{3}=0,333$

$X_{57}=\frac{1}{5}=0,200$ 
Tahap 2:

$$
\begin{aligned}
& R_{i j}=\frac{X_{i j}}{\text { Jumlah nilai semua } X_{i j}}=\operatorname{Hasil}(\text { Cost }) \\
& R_{07}=\frac{0,333}{0,333+0,333+0,333+0,200+0,333+0,200} \\
& =0,192 \\
& R_{17}=\frac{0,333}{0,333+0,333+0,333+0,200+0,333+0,200} \\
& =0,192 \\
& R_{27}=\frac{0,333}{0,333+0,333+0,333+0,200+0,333+0,200} \\
& =0,192 \\
& R_{37}=\frac{0,200}{0,333+0,333+0,333+0,200+0,333+0,200} \\
& =0,115 \\
& R_{47}=\frac{0,333}{0,333+0,333+0,333+0,200+0,333+0,200} \\
& =0,192 \\
& R_{57}=\frac{0,200}{0,333+0,333+0,333+0,200+0,333+0,200} \\
& =0,115
\end{aligned}
$$

(C8)

Tahap 1:

$$
\begin{aligned}
& X_{i j}=\frac{1}{\text { Nilai Kriteria }}=X_{i j} *(\text { Cost }) \\
& X_{08}=\frac{1}{3}=0,333 \\
& X_{18}=\frac{1}{5}=0,200 \\
& X_{28}=\frac{1}{3}=0,333 \\
& X_{38}=\frac{1}{4}=0,250 \\
& X_{48}=\frac{1}{5}=0,200 \\
& X_{58}=\frac{1}{3}=0,333
\end{aligned}
$$

Tahap 2:

$$
\begin{aligned}
& R_{i j}=\frac{X_{i j}}{\text { Jumlah nilai semua } X_{i j}}=\operatorname{Hasil}(\text { Cost }) \\
& R_{08}=\frac{0,333}{0,333+0,200+0,333+0,250+0,200+0,333} \\
& =0,202 \\
& R_{18}=\frac{0,200}{0,333+0,200+0,333+0,250+0,200+0,333} \\
& =0,121 \\
& R_{28}=\frac{0,333}{0,333+0,200+0,333+0,250+0,200+0,333} \\
& =0,202 \\
& R_{38}=\frac{0,250}{0,333+0,200+0,333+0,250+0,200+0,333} \\
& =0,152 \\
& R_{48}=\frac{0,200}{0,333+0,200+0,333+0,250+0,200+0,333} \\
& =0,121
\end{aligned}
$$

$$
R_{58}=\frac{0,333}{0,333+0,200+0,333+0,250+0,200+0,333}
$$

Dari perhitungan yang telah dilakukan tersebut di atas maka dapat diperoleh matriks keputusan yang telah dinormalisasikan adalah sebagai berikut:

$X=\left[\begin{array}{llllllll}0,182 & 0,211 & 0,227 & 0,208 & 0,238 & 0,208 & 0,192 & 0,202 \\ 0,182 & 0,105 & 0,227 & 0,125 & 0,238 & 0,125 & 0,192 & 0,121 \\ 0,136 & 0,158 & 0,136 & 0,167 & 0,190 & 0,167 & 0,192 & 0,202 \\ 0,182 & 0,211 & 0,045 & 0,167 & 0,048 & 0,167 & 0,115 & 0,152 \\ 0,136 & 0,211 & 0,136 & 0,125 & 0,238 & 0,125 & 0,192 & 0,121 \\ 0,182 & 0,105 & 0,227 & 0,208 & 0,048 & 0,208 & 0,115 & 0,202\end{array}\right]$

4. Menentukan normalisasi terbobot dari semua kriteria. Dapat dilakukan dengan cara melakukan perkalian matriks keputusan yang telah dinormalisasikan terhadap bobot kriteria.

$D_{01}=X_{01}^{*} * W_{1}=0,182 * 20=3,636$

$D_{11}=X_{11}^{*} * W_{1}=0,182 * 20=3,636$

$D_{21}=X_{21}^{*} * W_{1}=0,136 * 20=2,727$

$D_{31}=X_{31}^{*} * W_{1}=0,182 * 20=3,636$

$D_{41}=X_{41}^{*} * W_{1}=0,136 * 20=2,727$

$D_{51}=X_{51}^{*} * W_{1}=0,182 * 20=3,636$

$D_{02}=X_{02}^{*} * W_{2}=0,211 * 20=4,211$

$D_{12}=X_{12}^{*} * W_{2}=0,105 * 20=2,105$

$D_{22}=X_{22}^{*} * W_{2}=0,158 * 20=3,158$

$D_{32}=X_{32}^{*} * W_{2}=0,211 * 20=4,211$

$D_{42}=X_{42}^{*} * W_{2}=0,211 * 20=4,211$

$D_{52}=X_{52}^{*} * W_{2}=0,105 * 20=2,105$

$D_{03}=X_{03}^{*} * W_{3}=0,227 * 10=2,273$

$D_{13}=X_{13}^{*} * W_{3}=0,227 * 10=2,273$

$D_{23}=X_{23}^{*} * W_{3}=0,136 * 10=1,364$

$D_{33}=X_{33}^{*} * W_{3}=0,045 * 10=0,455$

$D_{43}=X_{43}^{*} * W_{3}=0,136 * 10=1,364$

$D_{53}=X_{53}^{*} * W_{3}=0,227 * 10=2,273$

$D_{04}=X_{04}^{*} * W_{4}=0,208 * 15=3,125$

$D_{14}=X_{14}^{*} * W_{4}=0,125 * 15=1,875$

$D_{24}=X_{24}^{*} * W_{4}=0,167 * 15=2,500$

$D_{34}=X_{34}^{*} * W_{4}=0,167 * 15=2,500$

$D_{44}=X_{44}^{*} * W_{4}=0,125 * 15=1,875$

$D_{54}=X_{54}^{*} * W_{4}=0,208 * 15=3,125$

$D_{05}=X_{05}^{*} * W_{5}=0,238 * 20=4,762$

$D_{15}=X_{15}^{*} * W_{5}=0,238 * 20=4,762$

$D_{25}=X_{25}^{*} * W_{5}=0,190 * 20=3,810$

$D_{35}=X_{35}^{*} * W_{5}=0,048 * 20=0,952$

$D_{45}=X_{45}^{*} * W_{5}=0,238 * 20=4,762$

$D_{55}=X_{55}^{*} * W_{5}=0,048 * 20=0,952$

$$
\begin{aligned}
& D_{06}=X_{06}^{*} * W_{6}=0,208 * 5=1,042 \\
& D_{16}=X_{16}^{*} * W_{6}=0,125 * 5=0,625 \\
& D_{26}=X_{26}^{*} * W_{6}=0,167 * 5=0,833 \\
& D_{36}=X_{36}^{*} * W_{6}=0,167 * 5=0,833 \\
& D_{46}=X_{46}^{*} * W_{6}=0,125 * 5=0,625 \\
& D_{56}=X_{56}^{*} * W_{6}=0,208 * 5=1,042 \\
& D_{07}=X_{07}^{*} * W_{7}=0,192 * 5=0,962
\end{aligned}
$$


$D_{17}=X_{17}^{*} * W_{7}=0,192 * 5=0,962$

$D_{27}=X_{27}^{*} * W_{7}=0,192 * 5=0,962$

$D_{37}=X_{37}^{*} * W_{7}=0,115 * 5=0,577$

$D_{47}=X_{47}^{*} * W_{7}=0,192 * 5=0,962$

$D_{57}=X_{57}^{*} * W_{7}=0,115 * 5=0,577$

$D_{08}=X_{08}^{*} * W_{8}=0,202 * 5=1,010$

$D_{18}=X_{28}^{*} * W_{8}=0,121 * 5=0,606$

$D_{28}=X_{28}^{*} * W_{8}=0,202 * 5=1,010$

$D_{38}=X_{38}^{*} * W_{8}=0,152 * 5=0,758$

$D_{48}=X_{48}^{*} * W_{8}=0,121 * 5=0,606$

$D_{58}=X_{58}^{*} * W_{8}=0,202 * 5=1,010$

Dari hasil perhitungan tersebut diatas, dapat diperoleh hasil matriks keputusan normalisasi terbobot metode aras adalah sebagai berikut:

$D=\left[\begin{array}{llllllll}3,636 & 4,211 & 2,273 & 3,125 & 4,762 & 1,042 & 0,962 & 1,010 \\ 3,636 & 2,105 & 2,273 & 1,875 & 4,762 & 0,625 & 0,962 & 0,606 \\ 2,727 & 3,158 & 1,364 & 2,500 & 3,810 & 0,833 & 0,962 & 1,010 \\ 3,636 & 4,211 & 0,455 & 2,500 & 0,952 & 0,833 & 0,577 & 0,758 \\ 2,727 & 4,211 & 1,364 & 1,875 & 4,762 & 0,625 & 0,962 & 0,606 \\ 3,636 & 2,105 & 2,273 & 3,125 & 0,952 & 1,042 & 0,577 & 1,010\end{array}\right]$

5. Menentukan nilai optimum dan derajat utilitas, nilai fungsi dari optimalisasi ( $\mathrm{Si}$ ), dengan cara menjumlahkan seluruh nilai kriteria dari hasil normalisasi terbobot,

$$
\begin{gathered}
S_{0}=3,636+4,211+2,273+3,125+4,762+1,042 \\
+0,962+1,010=21,020 \\
S_{1}=3,636+2,105+2,273+1,875+4,762+0,625 \\
+0,962+0,606=16,844 \\
S_{2}=2,727+3,158+1,364+2,500+3,810+0,833 \\
+0,962+1,010=16,363 \\
S_{3}=3,636+4,211+0,455+2,500+0,952+0,833 \\
+0,577+0,758=13,922 \\
S_{4}=2,727+4,211+1,364+1,875+4,762+0,625 \\
+0,962+0,606=17,131 \\
S_{5}=3,636+2,105+2,273+3,125+0,952+1,042 \\
+0,577+1,010=14,720
\end{gathered}
$$

Dari perhitungan ( $\mathrm{Si})$ di atas maka dapat diperoleh hasil seperti yang ditunjukkan pada Tabel 4 dan Tabel 5.

Tabel 4.

Hasil Perhitungan Si Metode Aras

\begin{tabular}{lcccc}
\hline \multicolumn{1}{c}{ Nama } & C1 & C2 & C3 & C4 \\
\hline Nilai Optimal & 3,636 & 4,211 & 2,273 & 3,125 \\
Sigid Ahmad Diyono & 3,636 & 2,105 & 2,273 & 1,875 \\
Irfan Zamrudi & 2,727 & 3,158 & 1,364 & 2,500 \\
Ardian Wiraksa & 3,636 & 4,211 & 0,455 & 2,500 \\
Eryanda Susilo & 2,727 & 4,211 & 1,364 & 1,875 \\
Joni Iskandar & 3,636 & 2,105 & 2,273 & 3,125 \\
& & & & \\
\hline
\end{tabular}

Tabel 5.

Lanjutan Hasil Perhitungan Si Metode Aras

\begin{tabular}{ccccc}
\hline C5 & C6 & C7 & C8 & Si \\
\hline 4,762 & 1,042 & 0,962 & 1,010 & 21,020 \\
4,762 & 0,625 & 0,962 & 0,606 & 16,844 \\
3,810 & 0,833 & 0,962 & 1,010 & 16,363 \\
0,952 & 0,833 & 0,577 & 0,758 & 13,922 \\
4,762 & 0,625 & 0,962 & 0,606 & 17,131 \\
0,952 & 1,042 & 0,577 & 1,010 & 14,720 \\
\hline
\end{tabular}

6. Menentukan nilai peringkat tertinggi dari setiap alternatif (Ki) dengan cara, membagi keseluruhan nilai dari setiap alternatif $(\mathrm{Si})$ terhadap nilai keseluruhan alternatif optimal $(\mathrm{AO})$.

$$
\begin{aligned}
& K_{0}=\frac{21,020}{21,020}=1,000 \\
& K_{1}=\frac{16,844}{21,020}=0,801 \\
& K_{1}=\frac{16,363}{21,020}=0,778 \\
& K_{1}=\frac{13,922}{21,020}=0,662 \\
& K_{1}=\frac{17,131}{21,020}=0,815 \\
& K_{1}=\frac{14,720}{21,020}=0,700
\end{aligned}
$$

7. Dari hasil perhitungan ARAS diatas dapat diperoleh hasil tabel tingkatan peringkat (Ki) dari setiap alternatif ditunjukan seperti pada Tabel 5 .

Tabel 5.

Hasil Perhitungan Ki Metode Aras

\begin{tabular}{clccc}
\hline Alternatif & \multicolumn{1}{c}{ Nama } & Si & Ki & Ranking \\
\hline A0 & Nilai Optimal & 21,020 & & \\
A1 & Sigid Ahmad Diyono & 16,844 & 0,801 & 2 \\
A2 & Irfan Zamrudi & 16,363 & 0,778 & 3 \\
A3 & Ardian Wiraksa & 13,922 & 0,662 & 5 \\
A4 & Eryanda Susilo & 17,131 & 0,815 & 1 \\
A5 & Joni Iskandar & 14,720 & 0,700 & 4 \\
\hline
\end{tabular}

Pada Tabel 5 dapat dijelaskan bahwa hasil dari perhitungan metode Aras, dimana nilai dari masing-masing alternatif dibagi dengan $A O$ sehingga menghasilkan nilai Utility Degree yang akan dijadikan tingkatan peringkat dengan nilai tertinggi yang dipilih. Sehingga dapat menentukan calon karyawan baru yang akan bekerja diperusahaan sesuai dengan tingakatan nilai atau peringkat yang diperoleh.

Hasil akhir dari perhitungan Metode Aras dibandingkan dengan data penelitian terdahulu mengunakan Metode Topsis (Technique For Others Reference by Similarity to Ideal Solution)[5] dalam penyeleksian calon karyawan, mempunyai akurasi sebesar 0,94 Menggunakan korelasi rank spearman. Dibandingkan dengan penggunakan metode ARAS dalam penentuan seleksi karyawan baru yang mempunyai akurasi sebesar 0,95 sehingga penggunaan Metode Aras untuk seleksi calon karyawan mempunyai akurasi yang cukup tinggi dibandingkan dengan Metode Topsis.

\subsection{Implementasi Sistem}

Implementasi sistem merupakan salah satu tahapan penting dalam pembuatan suatu sistem. Tahapan implementasi sistem dilakukan setelah proses analisis perancangan telah selesai. Berikut Tampilan Sistem Pendukung Keputsan Seleksi Calon Karyawan Baru dengan menggunkan Metode Aras.

1. Menu Login

Menu Login adalah halaman dimana user diminta untuk memasukan username dan password untuk memasuki sistem. 
Berikut rancangan user interface Form Login ditunjukan pada Gambar 2.

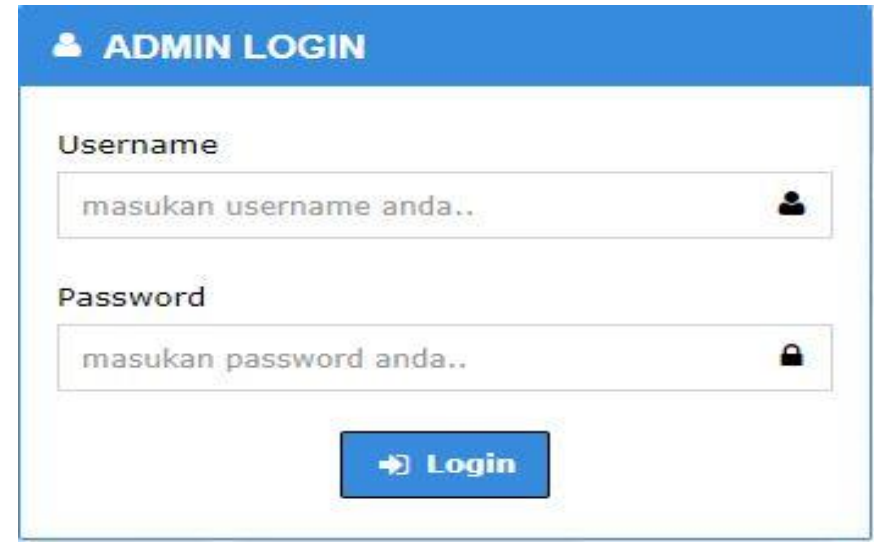

Gambar 2 Menu halaman login

\section{Menu Utama}

Menu Utama adalah halaman dashboard utama yang berisi menu dan sub menu. Berikut ini tampilan Menu Utama Sistem Pendukung Keputusan Seleksi Calon Karyawan Baru yang ditunjukan pada Gambar 3.

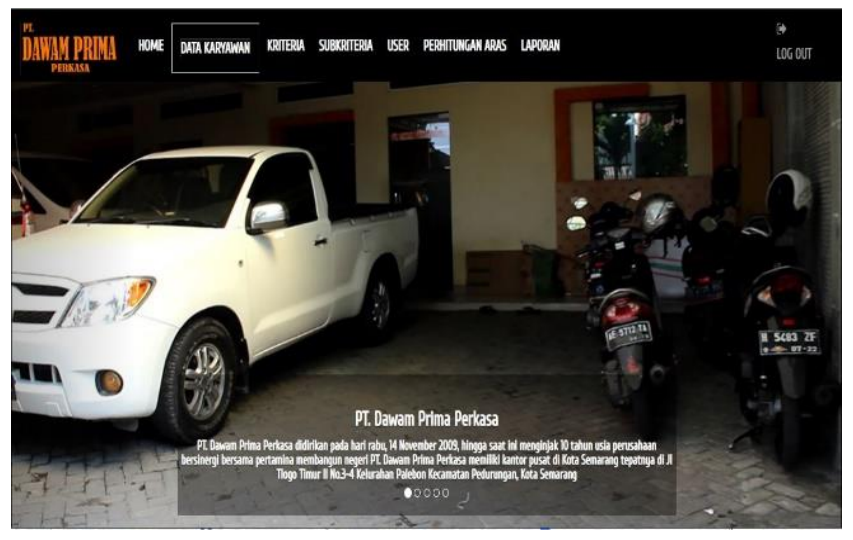

Gambar 3. Menu utama

\section{Menu Data Karyawan}

Merupakan Halaman Menu dimana menu data karyawan berisi biodata dari masing-masing karyawan yang akan mengikuti tes seleksi di perusahaan. Berikut tampilan halaman Menu Data Karyawan ditunjukan pada Gambar 4.
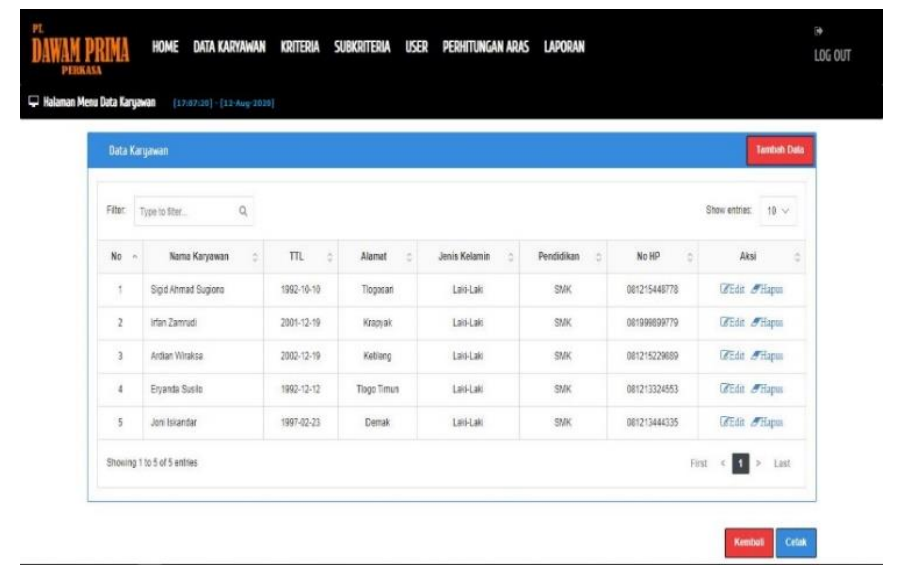

Gambar 4 Menu data karyawan
4. Menu Perhitungan Aras

Merupakan Halaman Menu dimana sistem bisa melakukan perhitungan data menggunakan metode Aras. Berikut tampilan Menu Perhitungan Aras ditunjukan pada Gambar 5.

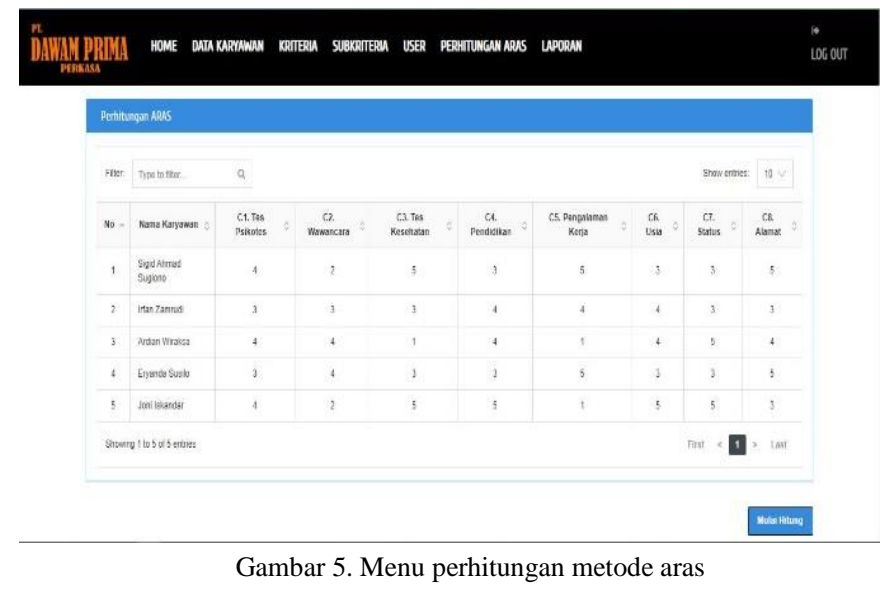

\section{Kesimpulan}

Dari hasil penelitian dan perhitungan yang telah dilakukan, bahwa metode ARAS dapat memberikan solusi terkait pemilihan calon karyawan baru PT. Dawam prima Perkasa. Berdasarkan hasil yang telah didapat menunjukan calon karyawan terbaik dapat dipilih oleh perusahaan untuk diterima dan bekerja di perusahaan. Dari hasil uji validasi korelasi rank spearman diperoleh nilai sebesar 0,95 yang artinya Metode ARAS dapat digunakan untuk menyeleksi calon karyawan baru pada PT. Dawam Prima Perkasa. Penelitian ini dalam membangun aplikasi sistem berbasis web masih mempunyai cukup kekurangan diantaranya adalah masih menggunakan sistem keamanan enkripsi MD5, fitur menu yang masih belum cukup lengkap karena beroperasi hanya untuk penyeleksian calon karyawan, sistem masih bersifat offline. Diharapkan untuk kedepanya ada pengembangan fitur menu dan penyempurnaan aplikasi pada sistem ini sehingga bisa dijadikan platform resmi seleksi calon karyawan PT. Dawam Prima secara online yang lebih baik lagi sehingga bisa untuk menyempurnakan aplikasi sistem dari penelitian ini.

\section{Referensi}

[1] Ismail and Nurjaya, "Menggunakan Metode Wp ( Weighted Product ) Dengan Bahasa," vol. 1, no. 1, pp. 28-32, 2016.

S. R. Cholil and L. D. A. P. Pertiwi, "A HYBRID Approach for Determine the Location of Stand Establishment at Batik Hatta Semarang," IJCCS (Indonesian J. Comput. Cybern. Syst., vol. 14, no. 3, p. 287, 2020, doi: 10.22146/ijccs.56206.

[3] R. Fachrizal, "IMPLEMENTASI ARAS ( Additive Ratio Assessment ) DALAM PEMILIHAN KASIR TERBAIK STUDI KASUS OUTLET CARDINAL STORE PLAZA MEDAN FAIR," Sainteks, no. Januari, pp. 501-510, 2019.

[4] D. S. Lutfi, "Sistem Pendukung Keputusan Penerimaan Dosen Baru Dengan Metode Simple Additive Weighting (Saw)," J. Teknol. Inf. dan Terap., vol. 4, no. 1, pp. 11-16, 2019, doi: 10.25047/jtit.v4i1.15. 
[5] H. Hertyana, "Seleksi Penerimaan Karyawan Baru Menggunakan Metode Topsis," Jitk, vol. 4, no. 2, pp. $1-8,2019$.

[6] D. Gustian, M. Nurhasanah, and M. Arip, "Sistem Pendukung Keputusan Seleksi Penerimaan Karyawan Dengan Metode Analytical Hierarchy Process," J. Komput. Terap., vol. 5, no. Vol 5 No 2 (2019), pp. 112, 2019, doi: 10.35143/jkt.v5i2.3336.

[7] S. A. P. Syafrida Hafni Sahir, "Analisis Penerapan Metode Additive Ratio Assessment ( ARAS ) Pada Pemberian Insentif Sales Penjualan Guna Mendukung Keputusan Manajemen," Semin. Nas. Teknol. Komput. Sains SAINTEKS, pp. 456-463, 2019.
[8] S. A. Joli Afriany, "Implementasi Metode ARAS Dalam Pemberian Keputusan Bonus Tahunan Karyawan," Semin. Nas. Teknol. Komput. Sains, no. 2018, pp. 484-491, 2019.

[9] N. Dicky and D. Sarjon, Multi Criteria Decision Making (MCDM) Pada Sistem Pendukung Keputusan. Yogyakarta: CV. BUDI UTAMA, 2017.

[10] C. Maulana, A. Hendrawan, and A. P. R. Pinem, "Pemodelan Penentuan Kredit Simpan Pinjam Menggunakan Metode Additive Ratio Assessment (Aras)," J. Pengemb. Rekayasa dan Teknol., vol. 15, no. 1 , p. 7, 2019, doi: 10.26623/jprt.v15i1.1483. 